\title{
Preventative and therapeutic effects of perindopril on hepatic fibrosis induced by bile duct ligation in rats
}

\author{
MASARU UEKI, MASAHIKO KODA, TOMOMITSU MATONO, TAKAAKI SUGIHARA, \\ KAZUNORI MAEDA and YOSHIKAZU MURAWAKI
}

Second Department of Internal Medicine, Tottori University, Faculty of Medicine, Nishi-cho 36-1, Yonago 683-8504, Japan

Received March 16, 2009; Accepted June 9, 2009

DOI: 10.3892/mmr_00000184

\begin{abstract}
The aim of this study was to examine the preventative and therapeutic effects of an angiotensin-converting enzyme inhibitor, perindopril, on cholestasis-induced liver fibrosis. Perindopril was administered orally for 21 days immediately after bile duct ligation at a dose of $2 \mathrm{mg} / \mathrm{kg}$ in order to evaluate the preventative effects, and for 21 days starting 3 weeks after bile duct ligation at doses of 2 and $8 \mathrm{mg} / \mathrm{kg}$ in order to evaluate the therapeutic effects. With regard to the preventative effects, perindopril reduced the hepatic hydroxyproline content by $33 \%$, collagen-I mRNA by $38 \%, \alpha$-smooth muscle actin $(\alpha-\mathrm{SMA})$-positive cells by $46 \%, \alpha$-SMA mRNA by $40 \%$, transforming growth factor- $\beta 1$ (TGF- $\beta 1$ ) mRNA by $21 \%$ and connective tissue growth factor (CTGF) mRNA by $27 \%$. With regard to the therapeutic effects, at $2 \mathrm{mg} / \mathrm{kg}$ perindopril had no inhibitory effects on the progression of liver fibrosis, but at $8 \mathrm{mg} / \mathrm{kg}$, it reduced hepatic hydroxyproline contents by $63 \%$, collagen-I mRNA by $94 \%$, TGF- $\beta 1$ mRNA by $79 \%$, CTGF mRNA by $97 \%$ and tissue inhibitor of metalloproteinase-1 mRNA by $87 \%$. Significant decreases in the oxidative stress markers hepatic 4-hydroxy-2-nonenal and 8-hydroxy-2deoxyguanosine were noted for perindopril administration at $8 \mathrm{mg} / \mathrm{kg}$, but not at $2 \mathrm{mg} / \mathrm{kg}$. In conclusion, perindopril had preventative and therapeutic effects on cholestasis-induced liver fibrosis through the inhibition of oxidative stress and/ or the activation of hepatic stellate cells, thus suggesting the possible application of perindopril as an antifibrotic drug.
\end{abstract}

\section{Introduction}

Angiotensin-II (ANG II) reportedly plays an important role in the pathogenesis of organ fibrosis, in addition to its role in

Correspondence to: Dr Masahiko Koda, Second Department of Internal Medicine, Tottori University, Faculty of Medicine, Nishi-cho 36-1, Yonago 683-8504, Japan

E-mail: masakoda@grape.med.tottori-u.ac.jp

Key words: bile duct ligation, hepatic stellate cells, liver fibrosis, oxidative stress, perindopril the regulation of systemic blood pressure, and has been shown to promote collagen synthesis by mesangial cells and cardiac fibroblasts (1-3). The blockade of ANG II by angiotensinconverting enzyme (ACE) inhibitors or by ANG II type 1 receptor (ATR1) antagonists inhibits the progression of organ fibrosis (4). In addition, ANG II has been shown to induce the proliferation and contraction of human hepatic stellate cells (HSCs) (5) and to stimulate transforming growth factor- $\beta 1$ (TGF- $\beta 1)$ mRNA expression in rat HSCs $(6,7)$.

In vivo studies have shown that ACE inhibitors or ATR1 antagonists attenuate the progression of experimental hepatic fibrosis (6-11). Clinical studies have also shown that ANG II blockers attenuate liver fibrosis in chronic hepatitis C $(12,13)$, nonalcoholic steatohepatitis (14) and hepatitis $\mathrm{C}$ recurrence after liver transplantation (15). Perindopril (PE) is clinically available as an ACE inhibitor for hypertension and has potent inhibitory effects on ACE in tissue. In this study, we examined the preventative and therapeutic effects, as well as the mechanisms of action, of PE on cholestasis-induced rat liver fibrosis.

\section{Materials and methods}

Animals. Male Wistar rats were purchased from Japan SLC Inc. (Shizuoka, Japan) and were maintained in a room at a controlled temperature of $24 \pm 2^{\circ} \mathrm{C}$ with a 12 -h light-dark cycle. Animals were given standard pellet chow and water ad libitum. Anesthesia was performed by intraperitoneally injecting pentobarbital (Dainippon Pharmaceutical, Japan) at a dose of $50 \mathrm{mg} / \mathrm{kg}$. All experiments were carried out in accordance with the Animal Experimentation Guidelines of Tottori University.

Establishment of the hepatic fibrosis model and administration of perindopril. Hepatic fibrosis was induced by bile duct ligation (BDL) as described previously (16). The common bile duct was double-ligated and cut between the ligatures. Control animals for BDL received a sham-operation in which they were subjected to midline incision and manipulation of the common bile duct without ligation.

We used the 3-week BDL rat model to study the preventative effects on the progression of hepatic fibrosis. The rats in the $\mathrm{BDL}+\mathrm{PE}$ group were orally administered PE once a day at a 
Table I. Primers used for detection of collagen-I, $\alpha$-SMA, TGF- $\beta 1$, CTGF, TIMP-1 and $\beta_{2}-\mathrm{MG}$.

Primer

\begin{tabular}{ll}
\hline Collagen-I & $\begin{array}{l}\text { Forward: 5'-TCCGGCTCCTGCTCCTCTTA-3' } \\
\text { Reverse: 5'-GTATGCAGCTGACTTCAGGGATGT-3' }\end{array}$ \\
$\alpha$-SMA & $\begin{array}{l}\text { Forward: 5'-CCTGCCAAGTATGATGACATCAAGA-3' } \\
\text { Reverse: 5'-GTAGCCCAGGATGCCCTTTAGT-3' }\end{array}$ \\
TGF- $\beta 1$ & Forward: 5'-GCAACAACGCAATCTATGAC-3' \\
& Reverse: 5'-CCTGTATTCCGTCTCCTT-3' \\
CTGF & Forward: 5'-TCCCTGCGACCCACACAA-3' \\
& Reverse: 5'-TGCAACTGCTTTGGAAGGACTC-3' \\
TIMP-1 & Forward: 5'-TCCTCTTGTTGCTATCATTGATAGCTT-3' \\
& Reverse: 5'-CGCTGGTATAAGGTGGTCTCGAT-3' \\
$\beta_{2}$-MG & Forward: 5'-CCGATGTATATGCTTGCAGAGTTAA-3' \\
& Reverse: 5'-CAGATGATTCAGAGCTCCATAGA-3'
\end{tabular}

$\alpha$-SMA, $\alpha$-smooth muscle actin; TGF- $\beta 1$, transforming growth factor- $\beta 1$; CTGF, connective tissue growth factor; TIMP-1, tissue inhibitor of metalloproteinase-1; $\beta_{2}$-MG, $\beta_{2}$-microglobulin.

dose of $2 \mathrm{mg} / \mathrm{kg}$ (Daiichi Co., Japan), which has been shown to be a clinically comparable dose (17), daily for 21 days immediately after surgery (survival rate, $n=8 / 10$ ). Rats in the BDL group (survival rate, $\mathrm{n}=7 / 10$ ) and in the sham group (survival rate, $n=5 / 5$ ) received vehicle once a day for the same period. On day 21, the animals were sacrificed under pentobarbital anesthesia. Blood was collected from the inferior vena cava. Part of the liver was fixed in $10 \%$ buffered formalin, while other specimens were immediately snap frozen and stored at $-80^{\circ} \mathrm{C}$.

In order to study the therapeutic effects on liver fibrosis, we used the 6-week BDL model. Rats in the BDL+PE group were orally administered PE once a day at 2 or $8 \mathrm{mg} / \mathrm{kg}$ daily for 21 days beginning 3 weeks after BDL surgery (survival rate, $n=7 / 10$ at $2 \mathrm{mg} / \mathrm{kg}$ and $\mathrm{n}=5 / 8$ at $8 \mathrm{mg} / \mathrm{kg}$ ). Rats in the BDL group (survival rate, $\mathrm{n}=6 / 10$ ) and in the sham group (survival rate, $n=5 / 5$ ) received vehicle once a day for the same period. Hepatic tissue and blood samples were collected on day 42 . Vitamin $\mathrm{K}(5 \mathrm{mg} / \mathrm{kg})$ was injected intramuscularly once a week in all groups.

Measurement of hepatic hydroxyproline (Hyp) content. Hepatic Hyp content was determined according to a previously described method (18) and was expressed as $\mu \mathrm{g}$ Hyp/g liver.

RNA extraction and reverse-transcription polymerase chain reaction $(P C R)$ analysis. Total RNA was isolated from homogenates of whole livers. RNA extraction was performed using Isogen (Nippon Gene Co., Toyama, Japan). RNA concentrations were determined by measuring the absorbance at $260 \mathrm{~nm}$, and RNA quality was verified by electrophoresis on an ethidium bromide-stained $1 \%$ agarose gel. Total RNA was reverse transcribed in a final volume of $20 \mu \mathrm{l}$ containing $1 \mathrm{X}$ RT buffer $(500 \mu \mathrm{M}$ each dNTP, $3 \mathrm{mM} \mathrm{MgCl} 2,75 \mathrm{mM} \mathrm{KCl}, 50 \mathrm{mM}$ Tris- $\mathrm{HCl}, \mathrm{pH} 8.3), 10 \mathrm{U}$ of Superscript II RNase $\mathrm{H}^{-}$reverse transcriptase (Gibco BRL, Life Technologies, Karlsruhe,
Germany), $1 \mu \mathrm{l}$ of $50 \mathrm{pmol} / \mu \mathrm{l}$ random primers (Promega, WI, USA), $0.5 \mu \mathrm{l}$ of $100 \mathrm{pmol} / \mathrm{ml}$ oligo dT and $1-5 \mu \mathrm{g}$ of total RNA. Samples were incubated at $20^{\circ} \mathrm{C}$ for $10 \mathrm{~min}$ followed by $42^{\circ} \mathrm{C}$ for $30 \mathrm{~min}$, and reverse transcriptase was inactivated by heating at $99^{\circ} \mathrm{C}$ for $5 \mathrm{~min}$ and cooling to $5^{\circ} \mathrm{C}$ for $5 \mathrm{~min}$.

Real-time PCR. Ten microliters of reverse transcriptase (RT) samples was used for quantitative real-time PCR. mRNA levels of collagen-I, $\alpha$-SMA, TGF- $\beta 1$, CTGF and tissue inhibitor of metalloproteinase-1 (TIMP-1) were assessed by real-time PCR assay (Light Cycler Fast Start DNA Master SYBR Green I; Roche Diagnostics, Tokyo, Japan) using $\beta_{2}$-microglobulin $\left(\beta_{2}-\mathrm{MG}\right)$ as a housekeeping gene. The forward and reverse primer sequences used are shown in Table I. Thermal cycler conditions were as follows: for collagen-I mRNA, hold at $95^{\circ} \mathrm{C}$ for $10 \mathrm{~min}$, repeat 40 cycles of $95^{\circ} \mathrm{C}$ for $10 \mathrm{sec}, 55^{\circ} \mathrm{C}$ for $10 \mathrm{sec}$, and $72^{\circ} \mathrm{C}$ for $3 \mathrm{sec}$; for $\alpha$-SMA mRNA, hold at $95^{\circ} \mathrm{C}$ for $10 \mathrm{~min}$, repeat 40 cycles of $95^{\circ} \mathrm{C}$ for $10 \mathrm{sec}, 55^{\circ} \mathrm{C}$ for 10 sec, and $72^{\circ} \mathrm{C}$ for $6 \mathrm{sec}$; for TGF- $\beta 1 \mathrm{mRNA}$, hold at $95^{\circ} \mathrm{C}$ for $10 \mathrm{~min}$, repeat $40 \mathrm{cycles}$ of $95^{\circ} \mathrm{C}$ for $10 \mathrm{sec}, 62^{\circ} \mathrm{C}$ for $10 \mathrm{sec}$, and $72^{\circ} \mathrm{C}$ for $9 \mathrm{sec}$; for CTGF mRNA, hold at $95^{\circ} \mathrm{C}$ for $10 \mathrm{~min}$, repeat 40 cycles of $95^{\circ} \mathrm{C}$ for $10 \mathrm{sec}, 55^{\circ} \mathrm{C}$ for $10 \mathrm{sec}$, and $72^{\circ} \mathrm{C}$ for $6 \mathrm{sec}$; for TIMP-1 mRNA, hold at $95^{\circ} \mathrm{C}$ for $10 \mathrm{~min}$, repeat 40 cycles of $95^{\circ} \mathrm{C}$ for $10 \mathrm{sec}, 55^{\circ} \mathrm{C}$ for $10 \mathrm{sec}$, and $72^{\circ} \mathrm{C}$ for $6 \mathrm{sec}$; for $\beta 2-\mathrm{MG} \mathrm{mRNA}$, hold at $95^{\circ} \mathrm{C}$ for $10 \mathrm{~min}$, repeat 40 cycles of $95^{\circ} \mathrm{C}$ for $10 \mathrm{sec}, 55^{\circ} \mathrm{C}$ for $10 \mathrm{sec}$, and $72^{\circ} \mathrm{C}$ for $5 \mathrm{sec}$.

Serum T-Bil, AST, ALT and ALP assays. Total-bilirubin (T-Bil), aspartate aminotransferase (AST), alanine aminotransferase (ALT) and alkaline phosphatase (ALP) levels in the serum were measured using an Autoanalyzer (Hitachi 7170, Tokyo, Japan).

Histological analysis. Sections $(4 \mu \mathrm{m})$ of formalin-fixed, paraffin-embedded livers were processed routinely for hematoxylin and eosin and azan staining. Immunohistochemical 
Table II. Biochemical data from the BDL models.

A, Three-week BDL model.

\begin{tabular}{lccc}
\hline & $\begin{array}{c}\text { Sham } \\
(\mathrm{n}=5)\end{array}$ & $\begin{array}{c}3 \mathrm{~W} \text { BDL } \\
(\mathrm{n}=7)\end{array}$ & $\begin{array}{c}3 \mathrm{~W} \text { BDL+PE }(2 \mathrm{mg} / \mathrm{kg}) \\
(\mathrm{n}=8)\end{array}$ \\
\hline T-Bil (mg/dl) & 0 & $6.4 \pm 0.26$ & $4.4 \pm 1.0$ \\
AST (IU/l) & $109 \pm 4.5$ & $649 \pm 36$ & $560 \pm 88$ \\
ALT (IU/l) & $45 \pm 1.8$ & $125 \pm 9.1$ & $108 \pm 11$ \\
ALP (IU/l) & $658 \pm 49$ & $1307 \pm 99$ & $1202 \pm 143$ \\
\hline
\end{tabular}

B, Six-week BDL model.

\begin{tabular}{lcccc}
\hline & $\begin{array}{c}\text { Sham } \\
(\mathrm{n}=5)\end{array}$ & $\begin{array}{c}6 \mathrm{~W} \text { BDL } \\
(\mathrm{n}=6)\end{array}$ & $\begin{array}{c}\text { 6W BDL+PE }(2 \mathrm{mg} / \mathrm{kg}) \\
(\mathrm{n}=7)\end{array}$ & $\begin{array}{c}6 \mathrm{~W} \text { BDL+PE }(8 \mathrm{mg} / \mathrm{kg}) \\
(\mathrm{n}=5)\end{array}$ \\
\hline T-Bil (mg/dl) & $0.060 \pm 0.0055$ & $7.3 \pm 0.61$ & $4.9 \pm 1.6$ & $1.5 \pm 1.4^{\mathrm{a}}$ \\
AST (IU/l) & $138 \pm 11$ & $955 \pm 448$ & $974 \pm 407$ & $294 \pm 119$ \\
ALT (IU/l) & $47 \pm 2.2$ & $170 \pm 78$ & $185 \pm 68$ & $73 \pm 13$ \\
ALP (IU/l) & $1041 \pm 50$ & $1271 \pm 65$ & $969 \pm 75$ & $1087 \pm 153$ \\
\hline
\end{tabular}

Values are the means \pm SEM. ${ }^{\mathrm{a}} \mathrm{p}<0.05$ compared with $6 \mathrm{~W}$ BDL group.

staining of $\alpha$-SMA was performed by the avidin-biotinperoxidase complex method. Semi-quantitative analyses of immuno-positive cells were carried out with the Adobe Photoshop Image Analyzing System (Adobe Systems Inc., CA, USA) in 10 intralobular ocular fields (magnification $x 400$ ) per specimen, excluding $\alpha$-SMA-positive cells in the portal area.

Analysis of lipid peroxidation and oxidative stress. Immunohistochemical staining for 4-hydroxy-2-nonenal (4-HNE) was performed using anti-4-HNE monoclonal antibody (Nikken Seil, Shizuoka, Japan) according to the manufacturer's instructions. Histological images of 4-HNE staining were randomly selected (magnification x200) and were classified into 4 grades based on the extent of 4-HNEpositive cytoplasmic staining. Immunohistochemical staining for 8-hydroxy-2-deoxyguanosine $(8-\mathrm{OHdG})$ was performed using anti-8-OHdG monoclonal antibody (Nikken Seil) according to the manufacturer's instructions. Analyses of immunopositive cells were carried out with the Adobe Photoshop Image Analyzing System in 10 fields (magnification x400) per specimen.

Statistical analysis. In order to assess the statistical significance of intergroup differences in the quantitative data, the MannWhitney test was performed (Stat View for Windows; SAS Institute Inc., NC, USA). p $<0.05$ was considered statistically significant. Values were expressed as the means \pm SEM.

\section{Results}

Biochemical analysis. BDL rats at 3 weeks (3W) and 6 weeks (6W) had higher levels of T-Bil, AST, ALT and ALP than sham rats. There were no significant differences between the serum
Table III. mRNA levels of collagen-I, $\alpha$-SMA, TGF- $\beta 1$, CTGF and TIMP-1 in livers of the 3-week BDL model.

\begin{tabular}{lccc}
\hline & $\begin{array}{c}\text { Sham } \\
(\mathrm{n}=5)\end{array}$ & $\begin{array}{c}3 \mathrm{~W} \text { BDL } \\
(\mathrm{n}=7)\end{array}$ & $\begin{array}{c}3 \mathrm{~W} \text { BDL+PE } \\
(2 \mathrm{mg} / \mathrm{kg})(\mathrm{n}=8)\end{array}$ \\
\hline Collagen-I mRNA & $1.0 \pm 0.20$ & $61 \pm 21$ & $38 \pm 16$ \\
$\alpha$-SMA mRNA & $1.0 \pm 0.20$ & $2.5 \pm 0.64$ & $1.5 \pm 0.44^{\mathrm{a}}$ \\
TGF- $\beta 1$ mRNA & $1.0 \pm 0.24$ & $9.5 \pm 4.1$ & $7.5 \pm 2.1$ \\
CTGF mRNA & $1.0 \pm 0.20$ & $5.9 \pm 2.7$ & $4.3 \pm 1.9$ \\
TIMP-1 mRNA & $1.0 \pm 0.26$ & $22 \pm 4.9$ & $20 \pm 4.5$ \\
\hline
\end{tabular}

Values are the means \pm SEM. ${ }^{\mathrm{a}} \mathrm{p}<0.05$ compared with the $3 \mathrm{~W}$ BDL group. $\alpha$-SMA, $\alpha$-smooth muscle actin; TGF- $\beta 1$, transforming growth factor- $\beta 1$; CTGF, connective tissue growth factor; TIMP-1, tissue inhibitor of metalloproteinase-1.

biochemical data of the $3 \mathrm{~W}$ BDL rats and the $3 \mathrm{~W} \mathrm{BDL}+\mathrm{PE}$ $(2 \mathrm{mg} / \mathrm{kg})$ rats.

Although low-dose $(2 \mathrm{mg} / \mathrm{kg})$ PE did not affect biochemical results in $6 \mathrm{~W}$ BDL+PE rats, high-dose $(8 \mathrm{mg} / \mathrm{kg}) \mathrm{PE}$ improved the serum levels of T-Bil, ALT and AST in 6W BDL+PE rats (Table II).

Preventative effects of perindopril on hepatic fibrosis induced by 3-week BDL. Histological analysis showed that PE administration markedly inhibited the progression of hepatic fibrosis and bile duct proliferation compared with rats in the $3 \mathrm{~W}$ BDL group (Fig. 1A-C). PE administration attenuated the increase in hepatic Hyp content (Fig. 2A) and the increase in mRNA levels of collagen-I (Table III). 

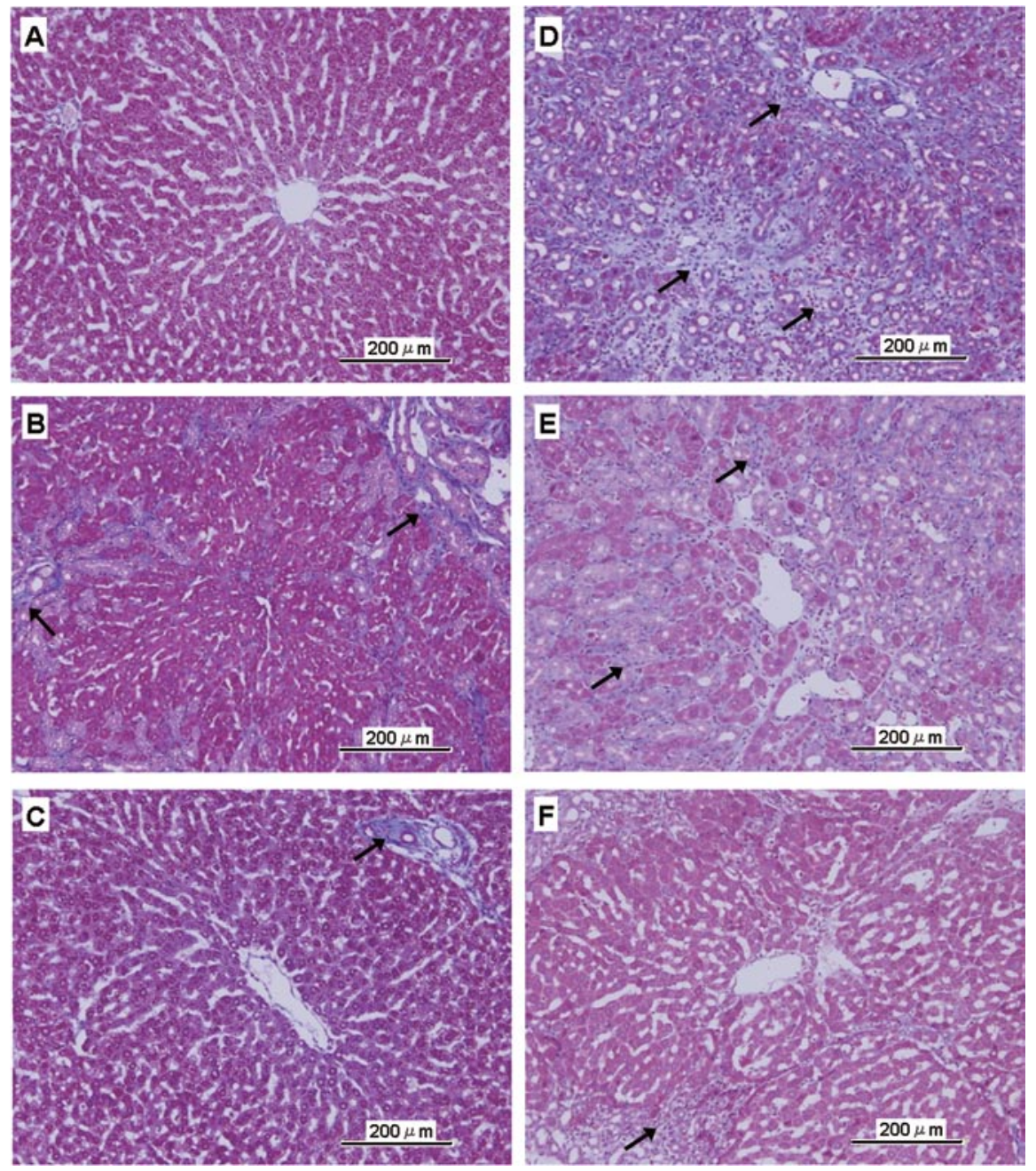

Figure 1. Preventative and therapeutic effects of perindopril (PE) on the progression of liver fibrosis in 3-week (3W) and 6-week (6W) BDL models. Azan staining, original magnification x100. (A) Sham, (B) $3 \mathrm{~W}$ BDL, (C) $3 \mathrm{~W}$ BDL+PE $(2 \mathrm{mg} / \mathrm{kg})$. Arrows indicate fibrosis in the portal and periportal area. PE reduced liver fibrosis compared with the $3 \mathrm{~W}$ BDL group. (D) $6 \mathrm{~W}$ BDL, (E) $6 \mathrm{~W}$ BDL+PE $(2 \mathrm{mg} / \mathrm{kg}),(\mathrm{F}) 6 \mathrm{~W}$ BDL+PE $(8 \mathrm{mg} / \mathrm{kg}) . \mathrm{PE}$ treatment $(8 \mathrm{mg} / \mathrm{kg}) \mathrm{markedly}$ reduced liver fibrosis and bile duct proliferation compared with the $6 \mathrm{~W}$ BDL group.

A.

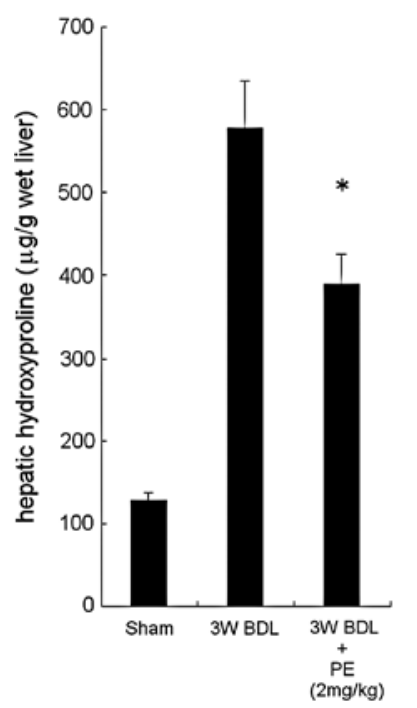

B.

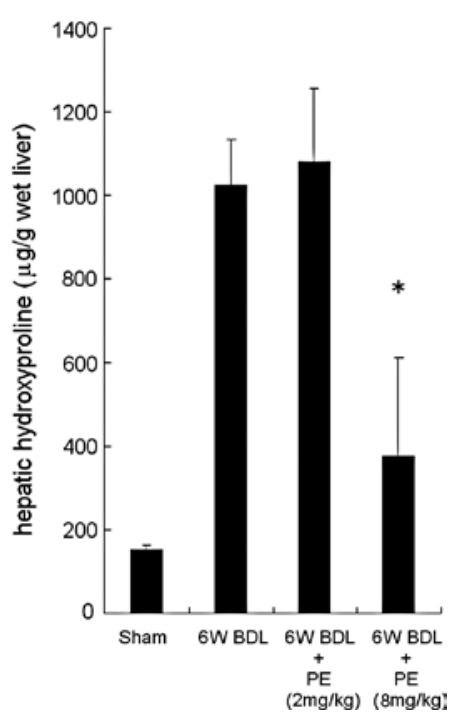

In order to clarify the mechanism by which PE attenuates the development of hepatic fibrosis induced by BDL, we examined $\alpha$-SMA-positive cells in the liver. PE administration tended to reduce the increase in $\alpha$-SMA-positive cells $(46 \pm 8.3$ for $3 \mathrm{~W}$ BDL and $25 \pm 8.7$ for $3 \mathrm{~W}$ BDL+PE; $\mathrm{p}=0.11$ ). PE also attenuated the increase in mRNA levels of $\alpha$-SMA and tended to attenuate the increase in mRNA levels of TGF- $\beta 1$ and CTGF, but not TIMP-1 (Table III).

Therapeutic effects of perindopril on hepatic fibrosis induced by 6 -week $B D L$. Liver histology showed that $8 \mathrm{mg} / \mathrm{kg}$ but not $2 \mathrm{mg} / \mathrm{kg}$ PE, administered from day 21 to 41 after BDL, improved hepatic fibrosis and bile duct proliferation caused by BDL (Fig. 1D-F). PE administration ( $8 \mathrm{mg} / \mathrm{kg}$ ) suppressed the increase in hepatic Hyp content by $63 \%$ (Fig. 2B) and reduced the increase in $\alpha$-SMA-positive cells in the livers of BDL rats $[83 \pm 13$ for $6 \mathrm{~W}$ BDL, $18 \pm 3.7$ for $6 \mathrm{~W}$ BDL+PE $(8 \mathrm{mg} / \mathrm{kg}) ; \mathrm{p}<0.01]$. PE administration at $8 \mathrm{mg} / \mathrm{kg}$ also reduced the increase in the mRNA levels of collagen-I, CTGF and TIMP-1, and tended to reduce the increase in the mRNA levels of $\alpha$-SMA and TGF- $\beta 1$ (Table IV).

Figure 2. (A) Hepatic hydroxyproline (Hyp) content in the 3-week BDL model. Sham $(n=5), 3 W$ BDL $(n=7), 3 W$ BDL+PE $(n=8)(* p<0.05$ compared with the $3 \mathrm{~W}$ BDL group). Perindopril (PE) significantly reduced hepatic Hyp content. (B) Hepatic Hyp content in the 6-week BDL model. Sham (n=5), 6W BDL $(\mathrm{n}=6), 6 \mathrm{~W}$ BDL+PE $(2 \mathrm{mg} / \mathrm{kg})(\mathrm{n}=7), 6 \mathrm{~W}$ BDL+PE $(8 \mathrm{mg} / \mathrm{kg}) \quad(\mathrm{n}=5)$ (means \pm SEM; ${ }^{*} \mathrm{p}<0.05$ compared with the $6 \mathrm{~W}$ BDL group). A high dose of PE significantly reduced the hepatic Hyp content. 
Table IV. mRNA levels of collagen-I, $\alpha$-SMA, TGF- $\beta 1$, CTGF-1 and TIMP-1 in the livers of the 6-week BDL model.

\begin{tabular}{|c|c|c|c|c|}
\hline & $\begin{array}{l}\text { Sham } \\
(\mathrm{n}=5)\end{array}$ & $\begin{array}{l}\text { 6W BDL } \\
\quad(n=6)\end{array}$ & $\begin{array}{c}6 \mathrm{~W} \text { BDL+PE }(2 \mathrm{mg} / \mathrm{kg}) \\
(\mathrm{n}=7)\end{array}$ & $\begin{array}{c}6 \mathrm{~W} \text { BDL+PE }(8 \mathrm{mg} / \mathrm{kg}) \\
(\mathrm{n}=5)\end{array}$ \\
\hline Collagen-I mRNA & $1.0 \pm 0.37$ & $376 \pm 234$ & $217 \pm 153$ & $24 \pm 22^{\mathrm{a}}$ \\
\hline$\alpha$-SMA mRNA & $1.0 \pm 0.58$ & $7.5 \pm 5.7$ & $4.5 \pm 1.6$ & $1.27 \pm 0.44$ \\
\hline TGF- $\beta 1$ mRNA & $1.0 \pm 0.16$ & $20 \pm 17$ & $16 \pm 5.1$ & $4.2 \pm 2.6$ \\
\hline CTGF mRNA & $1.0 \pm 0.10$ & $165 \pm 96$ & $81 \pm 39$ & $4.0 \pm 2.3^{\mathrm{a}}$ \\
\hline TIMP-1 mRNA & $1.0 \pm 0.13$ & $68 \pm 44$ & $58 \pm 19$ & $8.8 \pm 0.12^{\mathrm{a}}$ \\
\hline
\end{tabular}

Values are the means \pm SEM. ${ }^{\mathrm{a}} \mathrm{p}<0.05$ compared with $6 \mathrm{~W}$ BDL group. $\alpha$-SMA, $\alpha$-smooth muscle actin; TGF- $\beta 1$, transforming growth factor- $\beta 1$; CTGF, connective tissue growth factor; TIMP-1, tissue inhibitor of metalloproteinase-1.
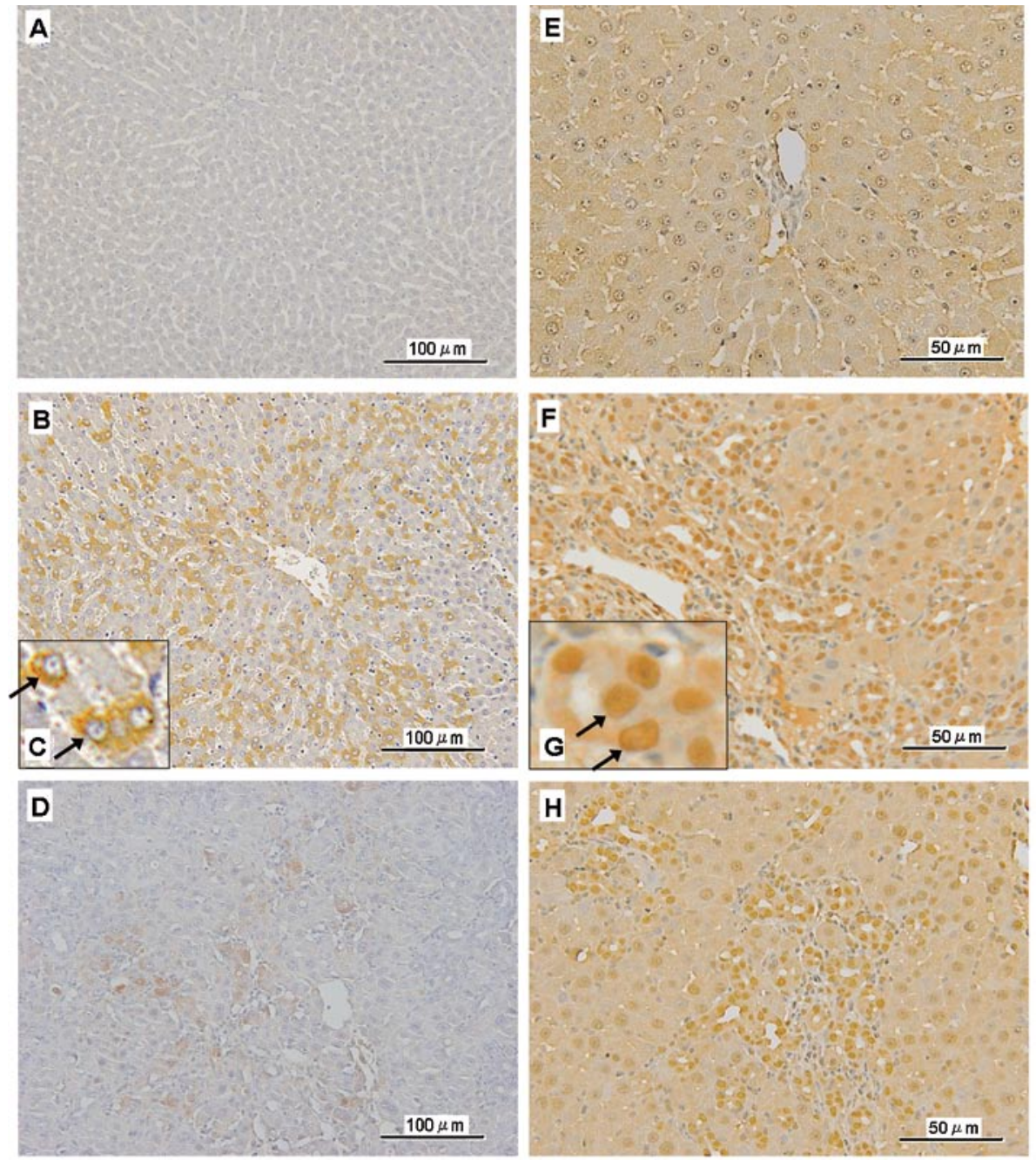

Figure 3. Immunohistochemistry of oxidative stress in the 3-week BDL model. (A-D) Immunohistochemical staining (original magnification x200) of 4-HNE in the 3-week BDL model. (A) Sham, (B) 3W BDL. (C) The high magnification image revealed cytoplasmic staining with 4-HNE (arrows). (D) 3W BDL+PE $(2 \mathrm{mg} / \mathrm{kg}$ ). (E-H) Immunohistochemical staining (original magnification x400) of 8-OHdG in the 3-week BDL model. (E) Sham, (F) 3W BDL. (G) The high magnification image revealed nucleic staining with $8-\mathrm{OHdG}$ (arrows). (H) 3W BDL+PE (2 mg/kg).

Influence on the oxidative stress of perindopril in the 3- and 6-week BDL livers. In order to examine the mechanisms by which PE reduces the activation of HSCs and the levels of fibrogenic cytokines, we immunohistochemically examined the specimens using the hepatic oxidative stress markers 4-HNE and 8-OHdG. 4-HNE immunostaining was stronger in the $3 \mathrm{~W}$ BDL group. This staining was markedly reduced by low-dose $(2 \mathrm{mg} / \mathrm{kg}) \mathrm{PE}$ administration in the 3-week BDL models $(\mathrm{p}<0.05)$ (Fig. 3A-D, Fig. 5A). 8-OHdG immunostaining was stronger in the $3 \mathrm{~W}$ BDL group. This staining tended to be reduced by low-dose PE $(\mathrm{p}=0.082)($ Fig. 3E-H, Fig. 5B). 

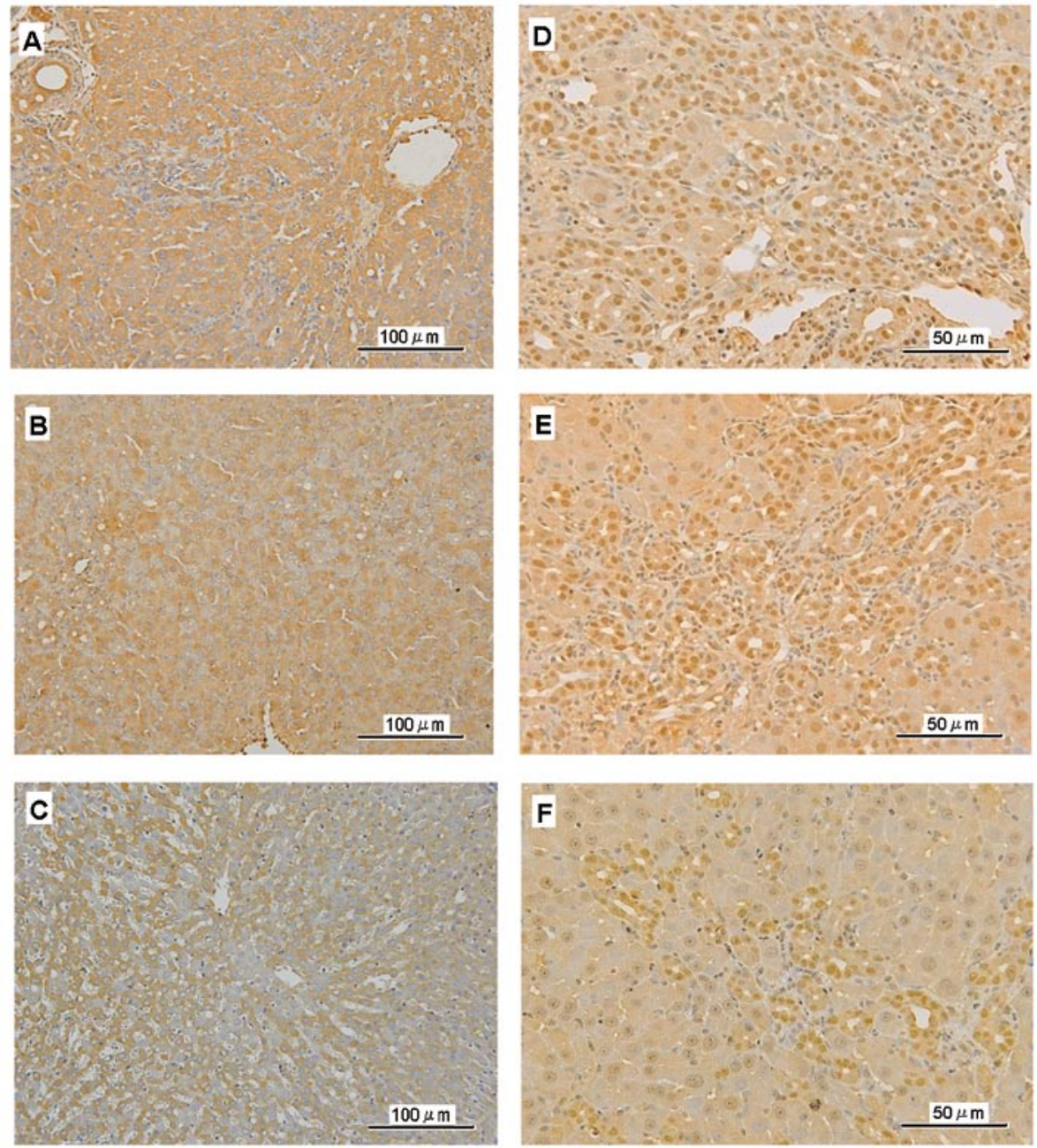

Figure 4. Immunohistochemistry of oxidative stress in the 6-week BDL model. (A-C) Immunohistochemical staining of 4-HNE in the 6-week BDL model. (A) $6 \mathrm{~W} \mathrm{BDL}$, (B) $6 \mathrm{~W} \mathrm{BDL}+\mathrm{PE}(2 \mathrm{mg} / \mathrm{kg}$ ), (C) $6 \mathrm{~W}$ BDL+PE $(8 \mathrm{mg} / \mathrm{kg}$ ) (original magnification $\mathrm{x} 200)$. (D-F) Immunohistochemical staining of $8-\mathrm{OHdG}$ in the 6-week BDL model. (D) 6W BDL, (E) 6W BDL+PE (2 mg/kg), (F) 6W BDL+PE $(8 \mathrm{mg} / \mathrm{kg})$.

A.

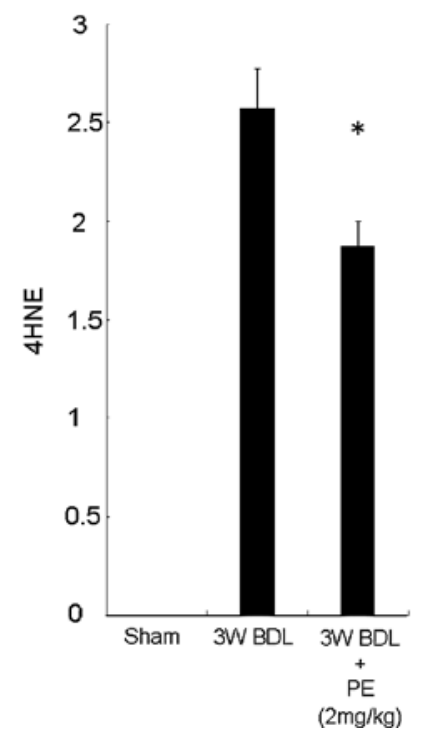

B.

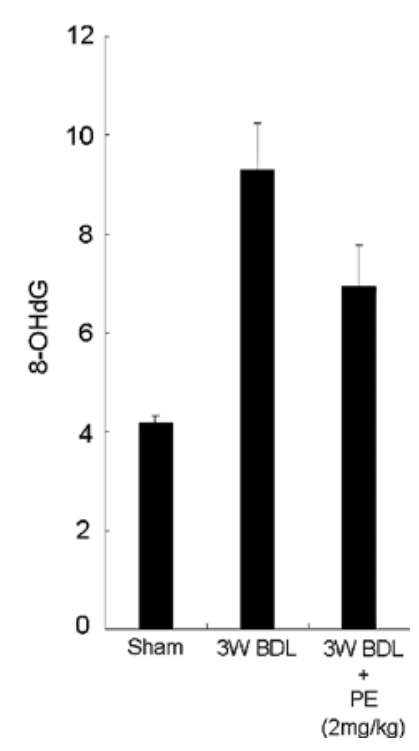

Figure 5. (A) Score classified into 4 grades based on 4-HNE-positive cytoplasmic staining in the 3-week BDL model (means \pm SEM; * $p<0.05$ compared with the 3W BDL group). (B) Number of 8-OHdG-immunopositive cells. Immunopositive cells were counted in 10 fields (magnification x400) per specimen. Perindopril (PE) administration decreased 4-HNE and 8-OHdG immunostaining.

In the 6-week BDL models, although low-dose $(2 \mathrm{mg} / \mathrm{kg})$ $\mathrm{PE}$ administration did not affect the expression of 4-HNE and 8-OHdG, high-dose $(8 \mathrm{mg} / \mathrm{kg}) \mathrm{PE}$ administration significantly decreased 4-HNE immunostaining (Fig. 4A-C, Fig. 6A) and 8-OHdG-positively stained cells (Fig. 4D-F, Fig. 6B).

\section{Discussion}

We evaluated the preventative and therapeutic effects of perindopril (PE) on BDL-induced hepatic fibrosis. The preventative effects were examined using a 21-day oral administration of PE immediately after BDL. We found that low-dose $(2 \mathrm{mg} / \mathrm{kg})$ PE prevented hepatic fibrosis induced by 3-week BDL with the suppression of collagen-I mRNA, TGF- $\beta 1$ mRNA and CTGF mRNA. TGF- $\beta 1$ and CTGF, a downstream mediator of TGF- $\beta 1$, are major profibrogenic cytokines (19). These cytokines also promote the activation, proliferation and extracellular matrix production of HSCs (20). In fact, we found that the number of activated HSCs ( $\alpha$-SMA-positive cells) was reduced by the administration of low-dose PE. The hepatic expression of TGF- $\beta 1 \mathrm{mRNA}$ and CTGF mRNA was lower in the BDL+PE group as compared to the BDL group. These findings indicate that PE administra- 
A.

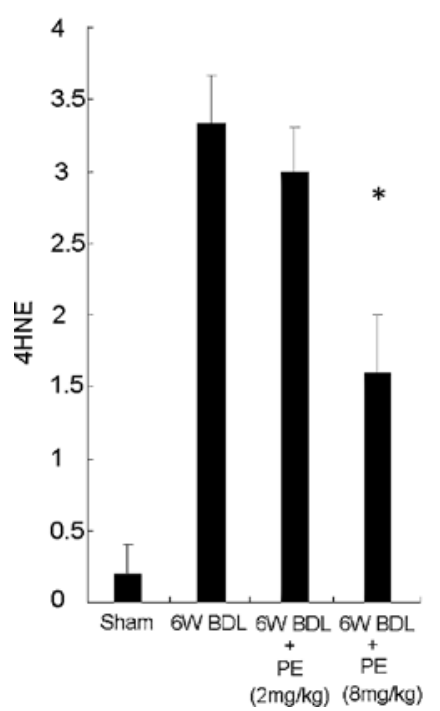

B.

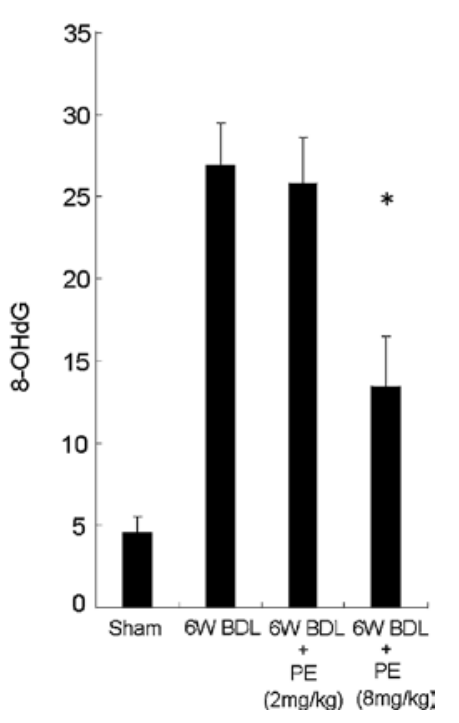

therapeutic effects on BDL-induced hepatic fibrosis (11). Compared with candesartan, PE does not exhibit more potent antifibrotic effects, for two reasons. First, PE is a prodrug and is converted to its active form, perindoprilate, by hydrolysis in the liver (23). As hydrolysis activity declines in the cirrhotic liver, PE may not be sufficiently converted to its active form. Secondly, the conversion of ANG II from ANG I is performed by both ACE and chymase, which is a chymotrypsin-like serine protease present in the secretory granules of mast cells. Komeda et al reported that chymase activity in human hepatic fibrosis increases with progression, and that ANG II-forming activity is more closely related to chymase activity than to ACE activity (24). Therefore, the inhibition of ACE activity alone may be insufficient to reduce the production of ANG II, and the antifibrotic effects of ACE inhibitors may therefore be weak compared to those of ANG II receptor antagonists.

In conclusion, we provide new evidence that perindopril exerts preventative and therapeutic effects on cholestasisinduced hepatic fibrosis by inhibiting the activation of HSCs, decreasing the production of profibrogenic cytokines, and reducing oxidative stress. of 8-OHdG-immunopositive cells. Immunopositive cells were counted in 10 fields (original magnification $\mathrm{x} 400$ ) per specimen (means \pm SEM; ${ }^{*} \mathrm{p}<0.05$ compared with the $6 \mathrm{~W}$ BDL group). Low-dose $(2 \mathrm{mg} / \mathrm{kg})$ perindopril (PE) administration did not affect 4-HNE and $8-\mathrm{OHdG}$ immunostaining, but high-dose PE administration significantly decreased 4-HNE and 8-OHdG immunostaining.

tion suppressed the activation of HSCs, as well as the synthesis of TGF- $\beta 1$ and CTGF. A similar preventative effect was reported for another ACE inhibitor, captopril (8), as well as for other ATR1 antagonists, olmesartan (9), irbesartan (21) and candesartan $(6,10,11)$.

We then evaluated the therapeutic effects of PE on BDLinduced hepatic fibrosis. These effects were examined using a 21-day oral administration of PE starting 3 weeks after BDL. Although low-dose $(2 \mathrm{mg} / \mathrm{kg})$ PE did not decrease the hepatic Hyp content in the 6-week BDL model, high-dose $(8 \mathrm{mg} / \mathrm{kg}) \mathrm{PE}$ significantly decreased the hepatic Hyp content as compared to the BDL group. In addition, PE decreased the hepatic mRNA expression of collagen-I, TGF- $\beta 1$, CTGF, TIMP-I and $\alpha$-SMA. This therapeutic effect of PE indicates that PE promotes the recovery of advanced fibrosis, such as the cirrhotic liver.

Since ANG II is reported to overproduce reactive oxygen species in vitro and in vivo and to induce the overexpression of cytosolic proteins involved in the activation of $\mathrm{NAD}(\mathrm{P}) \mathrm{H}$ oxidase, (22) we focused on oxidative stress as a profibrogenic factor. Oxidative stress activates HSCs, induces the secretion of growth factors and profibrogenic cytokines and stimulates collagen synthesis by HSCs. Oxidative stress is involved in the fibrogenesis-promoting effects of ANG II. The present study showed that 4-HNE and 8-OHdG were markedly increased in the livers of BDL rats, and that PE suppressed the increase in these markers in the preventative model at low doses and in the therapeutic model at high doses. These findings indicate that the antioxidant effects of PE play an important role in the prevention and treatment of hepatic fibrosis.

We previously demonstrated that low-dose $(2 \mathrm{mg} / \mathrm{kg})$ candesartan attenuates hepatic fibrosis in both 3-week BDL and 6-week BDL models, and that it has preventative and

\section{References}

1. Kagami S, Border WA, Miller DE and Noble NA: Angiotensin II stimulates extracellular matrix protein synthesis through induction of transforming growth factor- $\beta$ expression in rat glomerular mesangial cells. J Clin Invest 93: 2431-2437, 1994.

2. Sun Y, Zhang J, Zhang JQ and Ramires FJ: Local angiotensin II and transforming growth factor- $\beta 1$ in renal fibrosis of rats. Hypertension 35: 1078-1084, 2000.

3. Kupfahl C, Pink D, Friedrich K, et al: Angiotensin II directly increases transforming growth factor $\beta 1$ and osteopontin and indirectly affects collagen mRNA expression in the human heart. Cardiovasc Res 46: 463-475 2000.

4. Molteni A, Moulder JE, Cohen EF, et al: Control of radiationinduced pneumopathy and lung fibrosis by angiotensin-converting enzyme inhibitors and an angiotensin II type 1 receptor blocker. Int J Radiat Biol 76: 523-532, 2000

5. Bataller R, Gines P, Nicolas JM, et al: Angiotensin II induces contraction and proliferation of human hepatic stellate cells. Gastroenterology 118: 1149-1156, 2000.

6. Yoshiji H, Kuriyama S, Yoshii J, et al: Angiotensin-II type 1 receptor interaction is a major regulator for liver fibrosis development in rats. Hepatology 34: 745-750, 2001.

7. Ohishi T, Saito H, Tsusaka K, et al: Anti-fibrogenic effect of an angiotensin converting enzyme inhibitor on chronic carbon tetrachloride-induced hepatic fibrosis in rats. Hepatol Res 21: 147-158, 2001.

8. Jonsson JR, Clouston AD, Ando Y, et al: Angiotensin-converting enzyme inhibition attenuates the progression of rat hepatic fibrosis. Gastroenterology 121: 148-155, 2001.

9. Kurikawa N, Suga M, Kuroda S, Yamada K and Ishikawa H: An angiotensin II type 1 receptor antagonist, olmesartan medoxomil, improves experimental liver fibrosis by suppression of proliferation and collagen synthesis in activated hepatic stellate cells. Br J Pharmacol 139: 1085-1094, 2003.

10. Tuncer I, Ozbek H, Ugras S and Bayram I: Anti-fibrogenic effects of captopril and candesartan cilexetil on the hepatic fibrosis development in rat. Exp Toxic Pathol 55: 159-166, 2003.

11. Ueki M, Koda M, Yamamoto S, Matsunaga Y and Murawaki Y: Preventive and therapeutic effects of angiotensin II type 1 receptor blocker on hepatic fibrosis induced by bile duct ligation in rats. $\mathrm{J}$ Gastroenterol 41: 996-1004, 2006.

12. Terui Y, Saito T, Watanabe H, Togashi H and Kawata S: Effect of angiotensin receptor antagonist on liver fibrosis in early stages of chronic hepatitis C. Hepatology 36: 1022, 2002.

13. Ueki M, Koda M, Shimizu T, Mitsuta A, Yamamoto T and Murawaki Y: Effect of an angiotensin-II type-1 receptor blocker, candesartan on hepatic fibrosis in chronic hepatitis C: A prospective study. Hepatogastroenterology (In Press). 
14. Yokohama S, Yoneda M, Haneda M, et al: Therapeutic efficacy of an angiotensin II receptor antagonist in patients with nonalcoholic steatohepatitis. Hepatology 40: 1222-1225, 2004.

15. Rimola A, Londono MC, Guevara G, et al: Beneficial effect of angiotensin-blocking agents on graft fibrosis in hepatitis $\mathrm{C}$ recurrence after liver transplantation. Transplantation 78: 686-691, 2004.

16. Kountouras J, Billing BH and Scheuer PJ: Prolonged bile duct obstruction: a new experimental model for cirrhosis in the rat. $\mathrm{Br}$ J Exp Pathol 65: 305-311, 1984.

17. Yoshiji H, Kuriyama S, Kawata M, et al: The angiotensin-Iconverting enzyme inhibitor perindopril suppresses tumor growth and angiogenesis: possible role of the vascular endothelial growth factor. Clin Cancer Res 7: 1073-1078, 2001.

18. Murawaki Y and Hirayama C: Hepatic collagenolytic cathepsin in patients with chronic liver disease. Clin Chim Acta 108: 121-128, 1980.
19. Friedman SL: Liver fibrosis - from bench to bedside. J Hepatol 38: S38-S53, 2003.

20. Bataller R and Brenner DA: Liver fibrosis. J Clin Invest 115: 209-218, 2005.

21. Paizis G, Gilbert RE, Cooper ME, et al: Effect of angiotensin II type 1 receptor blockade on experimental hepatic fibrosis. J Hepatol 35: 376-385, 2001.

22. Bataller R, Schwabe RF, Choi YH, et al: NADPH oxidase signal transduces angiotensin II in hepatic stellate cells and is critical in hepatic fibrosis. J Clin Invest 112: 1383-1394, 2003.

23. Thiollet M, Funk-Brentano C, Grange JD, Midavaine M, Resplandy G and Jaillon P: The pharmacokinetics of perindopril in patients with liver cirrhosis Br J Clin Pharm 33: 326-328, 1992.

24. Komeda K, Jin D, Takai S, et al: Significance of chymasedependent angiotensin II formation in the progression of human liver fibrosis. Hepatol Res 38: 501-510, 2008. 